\title{
Do Prospective Teachers Care About PISA Studies? A Pilot Study among University Students in Germany
}

\author{
Olga Ioannidou ${ }^{1}$, Despoina Georgiou ${ }^{1}$, Andreas Obersteiner ${ }^{1}$, Nilüfer Deniz Baş ${ }^{1} \&$ Christine Mieslinger $^{1}$ \\ ${ }^{1}$ School of Education, Technical University Munich, Munich, Germany \\ Correspondence: Despoina Georgiou, Munich Center of Learning Sciences, Ludwig-Maximilians-Universität \\ München, Leopoldstrasse 44, 80802, Munich, Germany. Tel: 49-089-2180-72560. E-mail: \\ despoina.georgiou@psy.lmu.de
}

Received: November 7, 2016

Accepted: December 17, $2016 \quad$ Online Published: April 29, 2017

doi:10.5539/ies.v10n5p26

URL: https://doi.org/10.5539/ies.v10n5p26

\begin{abstract}
The results of international comparison studies such as the Program for International Student Assessment (PISA) have initiated intense discussions about educational reforms in Germany. Although in-service and pre-service teachers are an essential part of such reforms, little is known about their attitudes towards PISA studies. The present study aims to fill this gap through the investigation of pre-service teachers' awareness, interest, perception, and attitudes towards PISA. A questionnaire was used to survey a sample of 107 university students who were participating in a teacher education program. The results reveal that $100 \%$ of the participants are aware of PISA. Nearly $69 \%$ of the participants think that the impact of PISA is rather high or very high, while $41 \%$ of them believe that PISA results are reliable. Accordingly, half of the participants seem to be interested in PISA results for their country. The present study discusses these findings in the light of the expected outcomes as proposed in standards for teacher education.
\end{abstract}

Keywords: PISA studies, perception towards PISA, high stake assessment tests, interest in PISA, pre-service teachers' opinion

\section{Introduction}

In autumn 2013, the Organization for Economic Cooperation and Development (OECD) published the most recent results of the PISA assessment of 2012 (OECD, 2013). The original aim of PISA is to produce reliable results concerning student performance and educational systems to improve teaching and student performance in the countries themselves.

Germany is one of the countries which took actions to improve its educational system after PISA results. According to Neumann, Fischer and Kauertz (2010), PISA 2000 results revealed that German 15-year old students' performance in reading, mathematics, and science was equal and below the OECD (2013) average and a considerable percentage of students did not achieve even the lowest level of literacy, which is in contrast to the high expectations from earlier years. These results led to a reform of secondary education and nearly all social groups such as political parties, employers, trade unions, teachers' associations, parents' associations, and academic institutions supported these reforms (Ertl, 2006). One of the consequences was the introduction of the National Education Standards (NES) (Neumann, Fischer \& Kauertz, 2010) and standards for Teacher Education $(K M K, 2004)$. Through the introduction of educational standards, PISA results affected not only policy-making but also had an indirect impact on everyday teaching practices, educational goals, and teacher education.

However, as Hugonnier (2009) reported, teachers do not appear among stakeholders in studies investigating the impact of PISA results on policy-making. Surprisingly, teachers' opinion on PISA has not yet been investigated, although teachers undoubtedly play a crucial role in the educational process. The present study aims to fill the research gap concerning teachers' opinion towards PISA.

\section{Theoretical Background}

\subsection{Interpreting Test Results as a Facet of Teacher Competence}

The interpretation of high stake tests is an important aspect of teachers' competence. According to teaching standards in most countries, teachers are expected to be able to understand, interpret, analyze, and explain research results (Childs \& Lawson, 2003). In the US, for example, "The Standards for Teacher Competence in 
Educational Assessment of Students" (Association, N. E., 1990) include seven basic facets of teacher competence, four of which are related to the interpretation of large scale assessment results (Childs \& Lawson, 2003). In Germany, according to the new standards for Teacher Education (Kultusministerkonferenz [KMK], 2004), the graduates should be able to "recite and evaluate results of educational research" (KMK, 2004). Considering that university is often the first step of teacher professional development (Chong, Wong \& Quek, 2005), universities should equip future teachers with all the required skills for interpretation and presentation of such research findings.

Yet, it has repeatedly been reported that teachers' ability to interpret such data is limited and that they often need help to understand and work with large scale assessment tests, such as PISA (Black, 1994; Gipps, Brown, McCallum \& McAllister, 1995).

\subsection{Curriculum Reform and Teaching Practices}

As mentioned above, the latest PISA results led to educational reforms in Germany (Ertl, 2006). These reforms aspired to improve students' achievement by making changes, inter alia, in curricula. Since the aim of the reform was the improvement of student achievement and since teachers' behavior in the classroom crucially affects student achievement (Hattie, 2003), one would expect that teachers' daily practices were influenced significantly. In other words, it is assumed that in this top-down reform, teachers function as "mediators" between official changes and daily practices, or as "communicators" between the state and students. Hargreaves (1994) describes this dependence of classroom instruction by external factors, such as high stakes test, using the term "intensification".

This is pertinent because curricula do not only state what students should learn (National Council of Teachers of Mathematics [NCTM], 1989) but also provide guidelines for instruction (Ball \& Cohen, 1996). A study conducted by Wright (2002) revealed that, apart from other psychological impacts (e.g. stress), high stake tests impose limitations to lesson planning and instruction. A typical example of such limitations is given by Beam-Conroy (2001), who stated that there are five principles of teaching based on high stake test results: "high-stakes testing is king; high-stakes testing will take over your teaching; do what the tests demand or lose your job; high-stakes tests are scholastic Darwinism; high-stakes testing corrupts even well-meaning reforms". Nevertheless, it should not be taken for granted that all teachers adapt these guidelines in their teaching practices (Ball \& Cohen, 1996; Fullan \& Pomfret, 1977). Thus, the question that arises is how, and to what extent curricula change (change caused by the PISA results) influences the instruction of the teachers who follow them. Accordingly, one could question whether teachers adapt their instruction to new standards and whether they realize that some of the changes in the standards have been motivated by PISA.

In this context, pre-service teachers are also affected by curricula changes caused by high-stake tests (Gerwin, 2004; Flores \& Clark, 2003). This is because the role of pre-service teachers is dual. Primarily, they serve as classroom observers, as they are oftentimes asked to observe classrooms for the needs of their study programs (Flores, 2001). At the same time, pre-service teachers' perceptions can give an insight to teacher educators about the way that future teachers evaluate curricula changes (Flores \& Clark, 2003). Flowingly, one could question whether and how pre-service teachers are planning to follow instructional suggestions imposed by high stake test results.

\subsection{Teachers' and Pre-Service Teachers' Opinions of High Stake Tests}

As Jones and Egley (2004) argue, "The effects of high stake tests on teaching practices have been mixed." This means that high stake testing could have a positive, negative, or little to no effect on teachers' teaching practices (Cimbricz, 2002). But what do teachers think about high stake tests? Prior studies revealed that in-service and pre-service teachers' believe that when instruction is focused on high stake test results students are affected emotionally, physically and psychologically (Flores \& Clark, 2003). Furthermore, teachers report that they experience negative feeling themselves. Shame, embarrassment, guilt, and anger are some of the feelings reported by the teachers after the publication of high stake tests results (Smith, 1991). Most negative opinions and feelings about high stake tests originate from the perception that these tests are unable to capture the complexity of students' learning. In this context of critique, teachers argue that the results are used in ways that are invalid (Hoffman, Assaf, \& Paris, 2001). On the other hand, others point out the usefulness of these tests, claiming that they contribute to curriculum and instruction planning (Borko \& Stecher, 2001). Overall, however, teachers seem to agree that high stake tests cause anxiety and pressure to improve the test scores (Koretz, Mitchell, Barron, \& Keith, 1996). 


\subsection{Aim of the Study}

Considering the great impact of PISA results in educational policy-making and the key role that teachers have in the educational practice, it is surprising that no previous research has been done to illuminate teachers' awareness, interest, and opinions towards PISA. Accordingly, this study aims at shedding light on how teachers perceive PISA as a factor of change in educational systems and in their daily practices. In particular, this study focuses on pre-service teachers' perceptions, attitudes, awareness, and interest towards PISA.

\subsection{Research Questions}

The present study investigates pre-service teachers' opinion towards PISA. Because the term "opinion" is very general, this study focused on the investigation of four core concepts: awareness, perceptions, attitudes, and interest. The following research questions are addressed:

(1) Are pre-service teachers aware of PISA?

(2) What are pre-service teachers' perceptions and attitudes towards PISA?

(3) To what extent are pre-service teachers interested in PISA results?

\subsection{Definitions of the Four Core Concepts}

In this section, we define the four core concepts under investigation: awareness, perception, attitude, and interest. The rationale behind the selection of these concepts was the fact that they are in some sense hierarchical: To be aware of something, one must perceive the phenomenon, which is the basis for developing an attitude. Eventually, continual interest can emerge. Thus, the four concepts are presented in a "hierarchical" way, with awareness and perception as starting lines. In the following, every core concept is defined in detail.

Awareness is a concept that has been used in various ways (Rettie, 2003). As Schmidt (2002) stated "awareness has been used in increasingly contradictory ways... In fact, it is hardly a concept any longer." For example, for Dourish and Bly (1992) awareness is "an understanding of activities of others, which provides a context for your own activity," while according to Christiansen and Maglaughlin (2003), awareness is comprised of 41 different phrases which are part of four different types of awareness. In the present study, awareness is used in its simplest form, in the sense of having heard of PISA (as in, 'I am aware of PISA').

Perception is one of the basic cognitive functions, in the sense that it is a prerequisite for all the other processes of our cognitive system. In this study the term that will be used to describe perception is the one given by Gibson (1972) who argued that "perception is a bottom-up process, which means that sensory information is analyzed in one direction: from simple analysis of raw sensory data to ever increasing complexity of analysis through the visual system."

The third part of the hierarchy is the concept of attitude. According to Katz and Statland (1959), attitude is a tendency to evaluate an object or a symbol in a certain way (as cited in Weissman \& Beck, 1978). In this study, the concepts of perception and attitude are analyzed together as one concept (perception and attitude), given that perception is the prerequisite of attitude. In addition, attitude is the concept that can be easily measured via questionnaires compared to perception.

The final level of the hierarchy is the concept of interest. In this study, Krapp (1992) and Prenzel's (1988) definition introduced by the subject-object theory of interest is adopted (as cited in Heinze, Reiss, Rudolph, 2005). Interest is defined as a specific relation between a person (e.g. learner) and an object (e.g. learning topic). This interest is long term and independent of present situations (Heinze, Reiss, \& Rudolph, 2005).

\subsection{Expectations}

Because the present study is descriptive and, to our knowledge, no prior study investigating the same topic exists, no clear hypotheses can be established. However, we formulate expectations based on the available theory and empirical evidence (see theoretical background). According to Smith and Fey (2000), teachers are not "regarded as knowledgeable agents in the high-stakes debate". Nevertheless, given that PISA is intensively discussed in the public media, it is expected that students would be at least aware of PISA studies (Dixon, Mullers, Arndt, \& Hood, 2009). As stated by the teaching (KMK, 2004) and educational standards (e.g. National Evaluation Series [NES] as cited in Neumann, Fischer \& Kauertz, 2010), it is also expected that pre-service teachers in Germany would be exposed to a research-oriented university curriculum. Moreover, according to the above-mentioned standards, pre-service teachers should be well-informed about the latest research findings, such as PISA, and also be able to interpret and evaluate its findings. These skills would allow them to create a perception about what PISA is, what it is supposed to measure, and judge if it is successful or not. Accordingly, pre-service teachers are expected to present attitudes towards PISA findings and their importance. Since there is a lack of 
relevant literature about pre-service teachers' interest in PISA, or in large scale assessment tests, there is no clear expectation based on theory.

\section{Method}

\subsection{Instrument}

The questionnaire consisted of 27 items to assess the three constructs; awareness, attitude and perception, and interest. From the 27 items, four were binary and 23 were 5-point-Likert scale items.

\subsubsection{Awareness}

To assess pre-service teachers' awareness, four items were designed to investigate students' general knowledge about PISA studies, the school subjects assessed by PISA, and the latest PISA assessment period. Three items were dichotomously scored giving one point to the correct answer and zero to all the other options. One item was developed to measure students' awareness of other international assessment studies (e.g. TIMSS, TALIS). Participants got one point for every study that they knew. Moreover, a 5-point Likert scale item that ranged from 4 (very frequently) to 0 (never) was used to examine the sources from which students get information (e.g. university, television, newspapers).

\subsubsection{Attitude \& Perception}

To examine students' attitudes and perceptions, three subscales were created. In total, 13 items were created to measure pre-service teachers' attitudes and perceptions towards:

Subscale 1. Attitude \& Perception towards the impact of PISA. Three items referred to the current impact of PISA on policy-making, teaching methods, and curriculum in Germany. Additionally, three items referred to the impact of future PISA results on curriculum changes, pre-service teachers' future professional lives, and their teaching methods. The items were to be assessed along a 5-point Likert scale with ratings that ranged from 1 (none / very low) to 4 (very high), and 0 (don't know).

Subscale 2. Attitude \& Perception towards aims of PISA. Three items were used to assess to what extent pre-service teachers' think that the aims of PISA are accomplished. The items were to be assessed along a 5-point Likert scale with ratings that ranged from 1 (quite unsuccessfully) to 4 (successfully), and 0 (don't know).

Subscale 3. Attitude \& Perception towards results of PISA. Four items were constructed to evaluate pre-service teachers' attitude and perception towards results of PISA. The items were to be assessed along a 5-point Likert scale with ratings that ranged from 1 (strongly disagree) to 5 (strongly agree) and 3 (undecided).

\subsubsection{Interest}

Teacher students' personal interest in PISA results was measured by four items. A 5-point Likert scale from 1 (strongly disagree) to 5 (strongly agree) was answered, including a middle category 3 (undecided). Table 1 illustrates the three core constructs: the construct-related items, example items, and the used scales. Cronbach's Alpha for the scales interest $(\alpha=.84)$ and attitude and perception $(\alpha=.64)$ was sufficiently high.

Table 1. Constructs, number of items, example items, and scales

\begin{tabular}{|c|c|c|c|}
\hline Construct & Items & Example Items & Scale/Likert Scale \\
\hline Awareness & 5 & $\begin{array}{l}\text { "Have you ever heard of the Program } \\
\text { for International Student Assessment } \\
\text { (PISA)?" }\end{array}$ & "Yes" / "No" \\
\hline Perception \& Attitude & 8 & $\begin{array}{l}\text { "In your opinion what is the impact } \\
\text { of PISA on Policy-making?" }\end{array}$ & $\begin{array}{l}1=\text { "None/Very Low" } \\
4=\text { "Very high" }\end{array}$ \\
\hline Interest & 4 & $\begin{array}{l}\text { Please indicate your level of } \\
\text { agreement or disagreement with the } \\
\text { statement "I am interested in PISA } \\
\text { results for my country" }\end{array}$ & $\begin{array}{l}1=\text { "Strongly disagree" } \\
5=\text { "Strongly agree" }\end{array}$ \\
\hline
\end{tabular}

\subsection{Design and Participants}

To answer the research questions, a cross-sectional survey was conducted. For this purpose, the aforementioned questionnaire was distributed to the participants. Participants were 107 pre-service teachers (56 female [52\%], 49 male $[46 \%]$ and 2 other [2\%]) who studied at two large universities in the Southern part of Germany. This study 
aspired to survey pre-service mathematics teachers as the PISA 2012 focus was on mathematics. Therefore, the distribution of the questionnaire took place at three different mathematics classes. Participants followed a study program for teachers for the academic track of secondary school (Gymnasium; 75\%) or vocational schools (13\%) and $87 \%$ of the participants were in their first or second semester. The majority studied mathematics $(91 \%)$ as a main subject and the rest were divided into chemistry, physics, and German language or other. All participants studied in programs designed especially for teachers. Didactic courses were part of the study programs from the first semester. PISA studies and other high stake tests were explicitly introduced to all participants through courses or seminars as a part of their study curriculum (Mathematisches Institut Didaktik der Mathematik, 2016). Convenience sampling was used since no random selection was feasible. The evaluation was conducted as paper and pencil during regular mathematics classes under the supervision of the lecturer and took approximately 10 to 15 minutes to complete. The participation was voluntary.

\section{Results}

\subsection{Awareness}

Data analyses revealed that all the participants (100\%) were aware of PISA studies. Additionally, $72 \%$ of the responders were aware of at least one or more of the other existing large scale assessment tests. Furthermore, more than half of the responders (63\%) could correctly name the subjects that are tested by PISA and $76 \%$ knew the year that the last PISA results were published. Figure 1 illustrates the participants' preferred source of information about PISA studies. The vast majority of pre-service teachers get informed at the university, while only a small number of pre-service teachers choose newspapers, television, or internet.

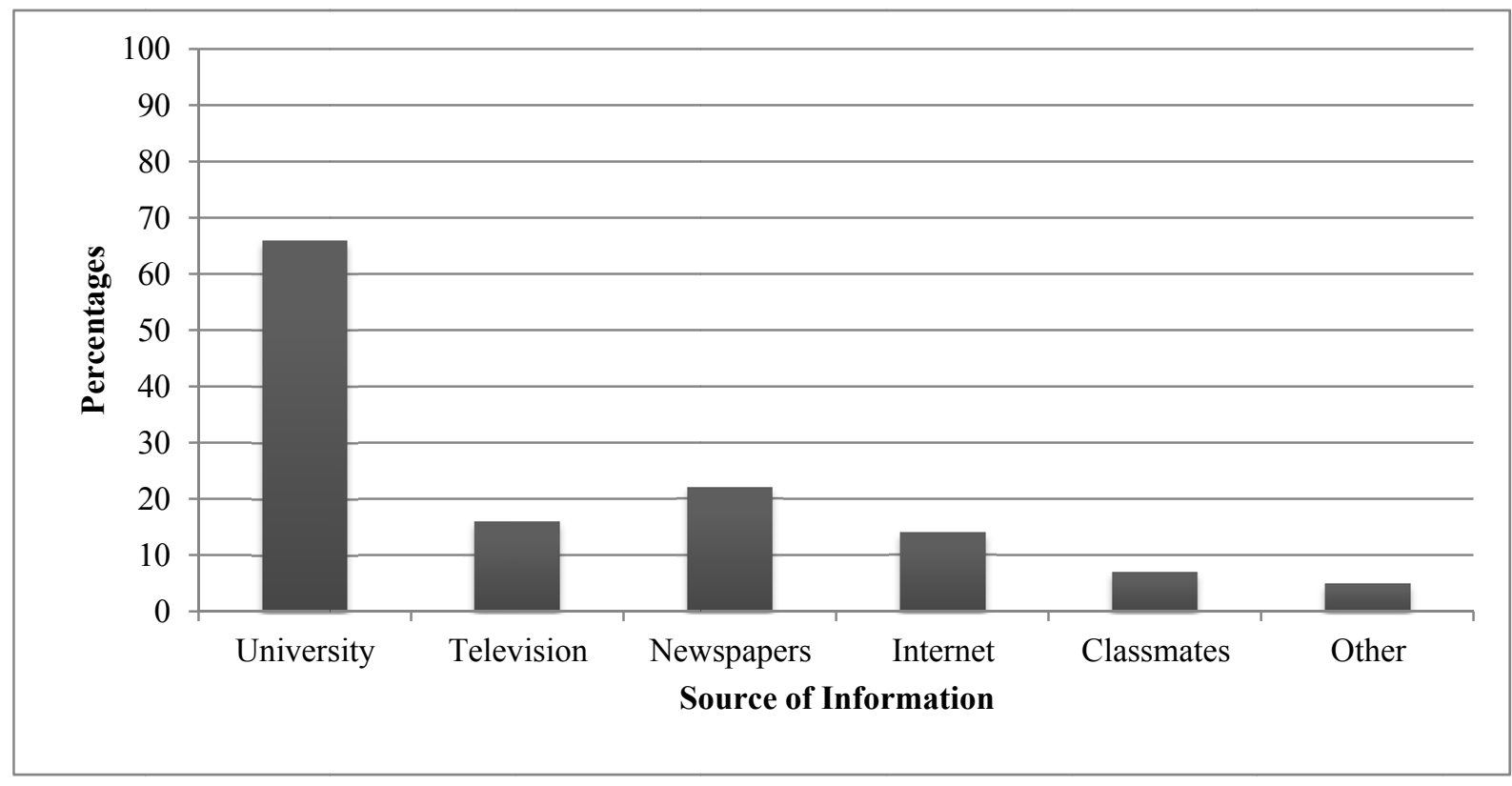

Figure 1. Participants' preferred source of information about PISA studies

\subsection{Attitudes and Perception}

Subscale 1. Most participants answered that the impact of PISA studies is -rather high / very high-in teaching methods (69\%) and in curriculum (69\%) in Germany. At the same time, nearly two thirds of them agreed that future PISA results will lead to curriculum changes, while $45 \%$ seemed to be undecided regarding the influence of PISA results to their future teaching methods.

Subscale 2. Concerning the aims of PISA studies, 55\% of the participants think that PISA measures -somewhat successfully / very successfully- the application of knowledge and skills in key subject areas.

Subscale 3. As for the reliability of the results relished by PISA, $41 \%$ of the participants believe that the results are reliable, while $39 \%$ are undecided (see Table 2). 
Table 2. Percentages in item response on Interest and Attitude \& Perception towards PISA

\begin{tabular}{|c|c|c|c|c|c|c|}
\hline & & $\begin{array}{l}\text { Strongly } \\
\text { Disagree }\end{array}$ & Disagree & Undecided & Agree & $\begin{array}{c}\text { Strongly } \\
\text { Agree }\end{array}$ \\
\hline 1 & I am interested in Pisa results for my country & 4 & 22 & 22 & 42 & 10 \\
\hline 2 & $\begin{array}{l}\text { When Pisa results are published I search for more } \\
\text { information }\end{array}$ & 38 & 29 & 22 & 10 & 1 \\
\hline 3 & I like to check Pisa rankings of student performance & 22 & 29 & 21 & 27 & 1 \\
\hline 4 & $\begin{array}{l}\text { I like to observe the changes of ranking lists among different } \\
\text { Pisa countries }\end{array}$ & 21 & 26 & 22 & 28 & 3 \\
\hline 5 & Pisa results are reliable & 6 & 14 & 39 & 35 & 6 \\
\hline 6 & $\begin{array}{l}\text { Pisa is a competition about student performances between } \\
\text { countries }\end{array}$ & 7 & 15 & 27 & 44 & 6 \\
\hline 7 & $\begin{array}{l}\text { Pisa results allow comparisons between countries' } \\
\text { educational systems }\end{array}$ & 6 & 23 & 24 & 41 & 7 \\
\hline 8 & $\begin{array}{l}\text { Pisa gives a clear image about the effectiveness of } \\
\text { educational systems }\end{array}$ & 10 & 28 & 35 & 25 & 2 \\
\hline 9 & $\begin{array}{l}\text { Pisa will have an impact on my future professional life as a } \\
\text { teacher }\end{array}$ & 15 & 15 & 22 & 44 & 4 \\
\hline 10 & Future Pisa results will lead to curriculum changes & 1 & 10 & 33 & 50 & 6 \\
\hline 11 & Future Pisa results will affect my teaching methods & 15 & 19 & 45 & 20 & 2 \\
\hline
\end{tabular}

Note. Items 8.1-8.4 Interest, Items 8.5-8.11 Attitude \& Perception

\subsection{Interest}

For this last scale, $42 \%$ of the participants seemed interested in PISA results for their country while $22 \%$ were undecided and $25 \%$ were not interested at all. Table 2 illustrates the percentages in item response on Interest and Attitude \& Perception towards PISA.

\section{Discussion}

The current paper investigated pre-service teachers' perception, attitudes, awareness, and interest towards PISA studies. As PISA still arouses a high level of interest throughout the media worldwide, participating countries initiated policy reforms and initiatives in direct response to the PISA evaluation. According to the standards of teacher education in Germany, graduates should be able to "recite and evaluate results of educational research" (KMK, 2004, p.12). Our sample consisted of pre-service teachers that studied in two of the most highly ranked universities in Germany (Technical University Munich and Ludwig-Maximilian-University Munich). In addition, Technical University Munich is responsible for analyzing and presenting PISA results for German students, we assumed that these two universities would include PISA and other high stakes test in their curricula, according to the standards of teacher education in Germany. Considering these circumstances, one would expect that participants of teacher study programs are well informed of PISA itself, show interest in results and integrate the research findings in their future professional life. Therefore, it is not a surprise that all participants of the current study have heard of PISA and, additionally, most of them knew at least one or more other existing large scale assessment test as well as the year of the latest released PISA results.

When the focus comes to the source of information about PISA, the university plays a central role for the students in terms of knowledge acquisition. This fact underlines the core function of the universities to provide the latest research findings to students (Chong, Wong \& Quek, 2005). In particular, the universities play a pivotal role in enhancing prospective teachers' competence to recite and evaluate results of educational research, as described in the KMK standards for teacher education (KMK, 2004). Surprisingly, other sources of information like internet, classmates, or television constitute an inferior role for the participants of the current study.

The results also revealed that only $41 \%$ of the participants agreed with the statement that PISA results are reliable. Yet, future research should further investigate pre-service teachers' ability to interpret and evaluate the results of high stake tests. Moreover, the finding that half of the participants see PISA as a competition about student performances between countries contradicts the role of PISA as presented by OECD. According to the OECD, the role of PISA studies is to improve teaching and student performance in the countries themselves rather than a competition between countries. Consequently, this finding should be further investigated in the future. 
This study also revealed that most participants do not search for further information when the results are published. This lack of interest could explain why they chose the university as the main source of information. Since the knowledge that they acquire in the university does not depend on their choice or interest, they do not seem to prefer other sources of information because perhaps they do not search for more information on the topic in general.

As for the impact of PISA, on the one hand, the participants approve the impact of PISA on teaching methods and curriculum in Germany. On the other hand, they are mostly undecided when it comes to the way that future PISA results will affect their teaching methods. This finding could be based on the circumstance that many participants attend the teacher study program in the first or second semester and therefore it is assumed that the participants have not developed their own practices yet.

To sum up, the present paper aspires to contribute to tightening the research gap in pre-service teachers' perception, attitudes, awareness, and interest towards PISA studies as no prior research on this particular topic exists. Additionally, it opens the path for further investigation and offers an informative basis for researchers in this field.

\section{Limitations}

Some limitations of the present study should be addressed. To conduct the current study pre-service teachers in Southern Germany were used. Therefore, the authors recommend that further research be extended to Federal States or nationwide, as well as the use of advanced sampling techniques. The sample consisted of a mixture of teacher study programs. Hence, future samples should be made up of only certain teacher study programs to differentiate the results more clearly. A distinction between participants of Lehramt Gymnasium and Vocational school was not possible in the present paper due to non-comparable numbers of participants. In addition, most of the teacher students majored in mathematics and future research should aim to include all subjects that are tested in PISA. Furthermore, the authors included a middle category -undecided-in the agreement scale to offer exhausting answer categories. While some results in the undecided category were quite high, the offer of answer possibilities in an open manner to identify the reasons for choosing this category seems useful.

\section{Suggestions}

Further educational research on pre-service and in-service teachers' perception, attitudes, awareness and interest towards PISA studies could build on the findings of the current study. Our assumptions for this study were based on the emphasis that the two universities put on PISA and other high stakes test results. Hence, it would be interesting for future studies to include pre-service and in-service teachers with limited access to sources and information about PISA and high stakes tests. The use of qualitative research methods, like the think-aloud method or interviews seems appropriate for this goal. The constructs of perception and attitude are concepts that should be especially investigated by qualitative data. In addition to the investigation of perception, attitudes, awareness, and interest, further research could highlight the degree of interpretation ability in teachers and pre-service teachers. Furthermore, in potential future research of the topic, there could be an examination of possible correlations between the constructs. The samples could be broadened and pre-service teachers from fields other than mathematics could be surveyed.

\section{Acknowledgments}

This work was supported by the German Research Foundation (DFG) and the Technische Universität München within the Open Access Publishing Funding Programme. The first and the second author contributed equally for the preparation of this work. The authors would like to thank April Christine Moeller for her valuable comments.

\section{References}

Association, N. E. (1990). Standards for teacher competence in educational assessment of students. Educational Measurement: Issues and Practice, 9(4), 30-32. https://doi.org/10.1111/j.1745-3992.1990.tb00391.x

Ball, D. L., \& Cohen, D. K. (1996). Reform by the book: What is: Or might be: The role of curriculum materials in teacher learning and instructional reform? Educational researcher, 25(9), 6-14. https://doi.org/10.3102/0013189X025009006

Beam-Conroy, T. (2001). Bamboozled by the Texas miracle. Rethinking Schools Online, 16(1).

Borko, H., \& Stecher, B. M. (Ed.) (2001). Looking at reform through different methodological lenses: Survey and case studies of the Washington state education reform.

Childs, R. A., \& Lawson, A. (2003). What do teacher candidates know about large-scale assessments? What should they know? Alberta journal of educational research, 49(4), 354. 
Chong, S. N. Y., Wong, I. Y. F., \& Quek, C. L. (2005). Pre-service teachers ${ }^{\mathrm{TM}}$ beliefs, attitudes and expectations: A review of the literature.

Christiansen, N., \& Maglaughlin, K. (Ed.) (2003). Crossing from physical workspace to virtual workspace: Be AWARE.

Cimbricz, S. (2002). State-mandated testing and teachers' beliefs and practice. education policy analysis archives, 10, 2. http://dx.doi.org/10.14507/epaa.v10n2.2002

Dixon, R., Arndt, C., Mullers, M., Vakkuri, J., Engblom-Pelkkala, K., \& Hood, C. (2013). A lever for improvement or a magnet for blame? Press and political responses to international educational rankings in four EU countries. Public Administration, 91(2), 484-505. https://doi.org/10.1111/padm.12013

Ertl, H. (2006). Educational standards and the changing discourse on education: the reception and consequences of the PISA study in Germany. Oxford Review of Education, 32(5), 619-634. https://doi.org/10.1080/03054980600976320

Flores, B. B., \& Clark, E. R. (2003). Texas voices speak out about high-stakes testing: Preservice teachers, teachers, and students. Current Issues in Education, 6.

Fullan, M., \& Pomfret, A. (1977). Research on curriculum and instruction implementation. Review of educational research, 47(2), 335-397. https://doi.org/10.3102/00346543047002335

Gerwin, D. (2004). Preservice teachers report the impact of high-stakes testing. The Social Studies, 95(2), 71-74. https://doi.org/10.3200/TSSS.95.2.71-74

Gibson, J. J. (1972). A theory of Direct Visual Perception. In J. Royce \& W. Rozenboom (Eds.). The Psychology of Knowing. New York: Gordon \& Breach.

Gipps, C. V. (1995). Intuition or evidence?: Teachers and national assessment of seven year olds. Assessing assessment. Buckingham, Bristol, PA: Open University Press.

Hargreaves, A. (1994). Changing teachers, changing times: Teachers' work and culture in the postmodern age: Teachers College Press.

Hattie, J. (2003). Teachers Make a Difference, What is the research evidence? Retrieved from http://research.acer.edu.au/research_conference_2003/4

Heinze, A., Reiss, K., \& Franziska, R. (2005). Mathematics achievement and interest in mathematics from a differential perspective. ZDM, 37(3), 212-220. https://doi.org/10.1007/s11858-005-0011-7

Hoffman, J. V., Assaf, L. C., \& Paris, S. G. (2001). High-stakes testing in reading: Today in Texas, tomorrow? The reading teacher, 54(5), 482-492.

Hugonnier, B. (2009). Pisa and the performance of educational systems. Paris: Organization for Economic Cooperation and Development.

Jones, B. D., \& Egley, R. J. (2004). Voices from the frontlines: Teachers' perceptions of high-stakes testing. education policy analysis archives, 12, 39. http://dx.doi.org/10.14507/epaa.v12n39.2004

KMK. (2004). Standards Lehrerbildung: Bildungswissenschaften: Beschluss der Kultusministerkonferenz vom 16.12.2004. Retrieved from http://www.kmk.org/fileadmin/veroeffentlichungen_beschluesse/2004/2004_12 _16-Standards-Lehrerbildung.pdf

Koretz, D., Mitchell, K., Barron, S., \& Keith, S. (1996). Final report: Perceived effects of the Maryland school performance assessment program. Los Angeles, CA: CRESST.

Mathematisches Institut Didaktik der Mathematik. (2016).Retrieved December 16, 2016, from http://www.math.lmu.de/ didaktik/index.php?data=lehre

Neumann, K., Fischer, H. E., \& Kauertz, A. (2010). From PISA to educational standards: The impact of large-scale assessments on science education in Germany. International Journal of Science and Mathematics Education, 8(3), 545-563. https://doi.org/10.1007/s10763-010-9206-7

OECD. (2007), PISA 2006: Science Competencies for Tomorrow's World: Volume 1: Analysis, OECD Publishing, Paris. http://dx.doi.org/10.1787/9789264040014-en

OECD. (2013), Education at a Glance 2013: OECD Indicators. OECD Publishing, Paris. http://dx.doi.org/10.1787/eag-2013-en 
Rettie, R. (2003). Connectedness, awareness and social presence: Paper presented at the sixth International Presence Workshop, Aalborg, Denmark. Retrieved from https://www.researchgate.net/publication/38175268 _Connectedness_Awareness_and_Social_Presence

Schmidt, K. (2002). The problem with awareness': Introductory remarks on awareness in CSCW'. Computer Supported Cooperative Work (CSCW), 11(3-4), 285-298. https://doi.org/10.1023/A:1021272909573

Smith, M. L., \& Fey, P. (2000). Validity and Accountability in High-Stakes Testing. Journal of Teacher Education, 51(5), 334-344. https://doi.org/10.1177/0022487100051005002

Weissman, A. N., \& Beck, A. T. (1978). Development and validation of the Dysfunctional Attitude Scale: A preliminary investigation. Retrieved from http://files.eric.ed.gov/fulltext/ED167619.pdf

Wright, W. E. (2002). The effects of high stakes testing in an inner-city elementary school: The curriculum, the teachers, and the English language learners. Current Issues in Education, 5.

\section{Appendix}

\section{Tables with the scale items in English and German for every core concept}

Table A1. Scale items for the concept of awareness in English and German

\begin{tabular}{|c|c|}
\hline \multicolumn{2}{|c|}{ Awareness } \\
\hline $\begin{array}{l}\text { Have you ever heard of the Program for } \\
\text { International Student Assessment (PISA)? }\end{array}$ & Haben Sie je von der PISA-Studie gehört? \\
\hline When were the last PISA results released? & $\begin{array}{l}\text { Wann wurden die letzten PISA-Ergebnisse } \\
\text { veröffentlicht? }\end{array}$ \\
\hline Which subjects does PISA focus on? & $\begin{array}{l}\text { Mit welchem Fach/welchen Fächern beschäftigt sich } \\
\text { PISA? }\end{array}$ \\
\hline $\begin{array}{l}\text { How often do you get information on PISA from the } \\
\text { following sources? }\end{array}$ & $\begin{array}{l}\text { Wie oft erhalten Sie Informationen über die PISA-Studie } \\
\text { von den folgenden Quellen? }\end{array}$ \\
\hline
\end{tabular}

Table A2. Scale items for the concept of perception and attitude in English and German

\begin{tabular}{|c|c|}
\hline \multicolumn{2}{|c|}{ Perception and Attitude } \\
\hline $\begin{array}{l}\text { In your opinion, what is the impact of Pisa on } \\
\text { policy-making in Germany? }\end{array}$ & $\begin{array}{l}\text { Welche Auswirkungen hat PISA Ihrer Meinung nach auf } \\
\text { die Politischen Entscheidungen? }\end{array}$ \\
\hline $\begin{array}{l}\text { In your opinion, what is the impact of Pisa on } \\
\text { teaching methods? }\end{array}$ & $\begin{array}{l}\text { Welche Auswirkungen hat PISA Ihrer Meinung nach auf } \\
\text { die Lehrmethoden? }\end{array}$ \\
\hline $\begin{array}{l}\text { In your opinion, what is the impact of Pisa on } \\
\text { curriculum? }\end{array}$ & $\begin{array}{l}\text { Welche Auswirkungen hat PISA Ihrer Meinung nach auf } \\
\text { den Lehrplan? }\end{array}$ \\
\hline $\begin{array}{l}\text { PISA aims at measuring students' competencies } \\
\text { in application of knowledge and skills in key } \\
\text { subject areas }\end{array}$ & $\begin{array}{l}\text { PISA zielt darauf ab, die Kompetenzen von Schülern in } \\
\text { Anwendung von Wissen und Fertigkeiten in Kerngebieten } \\
\text { zu messen }\end{array}$ \\
\hline $\begin{array}{l}\text { S at measuring students' competencies } \\
\text {, reasoning and communication }\end{array}$ & $\begin{array}{l}\text { rauf ab, die Kompetenzen von Schülern in } \\
\text { ches Denken und Kommunikation zu messen }\end{array}$ \\
\hline $\begin{array}{l}\text { PISA aims at measuring students' competencies } \\
\text { in apposition, solution and interpretation of } \\
\text { problems in a variety of situation }\end{array}$ & $\begin{array}{l}\text { PISA zielt darauf ab, die Kompetenzen von Schülern in } \\
\text { Positionieren, Lösen und Interpretieren von Problemen in } \\
\text { verschiedenen Situationen zu messen }\end{array}$ \\
\hline Pisa results are reliable & PISA-Ergebnisse sind glaubwürdig \\
\hline $\begin{array}{l}\text { a is a competition about student performances } \\
\text { tween countries }\end{array}$ & $\begin{array}{l}\text { PISA ist ein Wettstreit zwischen Ländern bezüglich der } \\
\text { Schülerleistung }\end{array}$ \\
\hline $\begin{array}{l}\text { Pisa results allow comparisons between } \\
\text { countries' educational systems }\end{array}$ & $\begin{array}{l}\text { PISA erlaubt Vergleiche zwischen den verschiedenen } \\
\text { Bildungssystemen }\end{array}$ \\
\hline
\end{tabular}


Pisa gives a clear image about the effectiveness of educational systems

Pisa will have an impact on my future professional life as a teacher

Future Pisa results will lead to curriculum changes

Future Pisa results will affect my teaching methods
PISA legt klar die Effektivität von Bildungssystemen offen

PISA wird mein zukünftiges Arbeitsleben beeinflussen

Zukünftige PISA-Ergebnisse werden den Lehrplan verändern

Zukünftige PISA-Ergebnisse werden meine Lehrmethoden beeinflussen

Table A3. Scale items for the concept of Interest in English and German

\begin{tabular}{|c|c|}
\hline \multicolumn{2}{|r|}{ Interest } \\
\hline I am interested in Pisa results for my country & Ich interessiere mich für die PISA-Ergebnisse meines Landes \\
\hline $\begin{array}{l}\text { When Pisa results are published I search for } \\
\text { more information }\end{array}$ & $\begin{array}{l}\text { Nach Bekanntgabe von PISA-Ergebnissen suche ich nach } \\
\text { weiteren Informationen zum Thema }\end{array}$ \\
\hline $\begin{array}{l}\text { I like to check Pisa rankings of student } \\
\text { performance }\end{array}$ & Ich informiere mich gerne über Ranglisten zur Schülerleistung \\
\hline $\begin{array}{l}\text { I like to observe the changes of ranking lists } \\
\text { among different Pisa countries }\end{array}$ & $\begin{array}{l}\text { Ich beobachte gerne Veränderungen in den PISA-Ergebnislisten } \\
\text { zwischen den teilnehmenden Ländern }\end{array}$ \\
\hline
\end{tabular}

\section{Copyrights}

Copyright for this article is retained by the author(s), with first publication rights granted to the journal.

This is an open-access article distributed under the terms and conditions of the Creative Commons Attribution license (http://creativecommons.org/licenses/by/4.0/). 